\title{
Expression analysis of candidate genes for chronic subclinical mastitis in Norwegian Red cattle
}

\author{
E. Kirsanova, ${ }^{1 *}$ ๑ P. Boysen, ${ }^{2}$ () G. M. Johansen, ${ }^{2}$ B. Heringstad, ${ }^{3} \oplus$ A. Lewandowska-Sabat,,${ }^{1,4}$ \\ and I. Olsaker ${ }^{1}$ (1) \\ ${ }^{1}$ Department of Basic Sciences and Aquatic Medicine, Faculty of Veterinary Medicine, Norwegian University of Life Sciences, Oslo NO-0102, \\ Norway \\ ${ }^{2}$ Department of Food Safety and Infection Biology, Faculty of Veterinary Medicine, Norwegian University of Life Sciences, Oslo NO-0102, Norway \\ ${ }^{3}$ Department of Animal and Aquacultural Sciences, Faculty of Biosciences, Norwegian University of Life Sciences, Ås NO-1432, Norway \\ ${ }^{4}$ Research Support Office, Norwegian University of Life Sciences, Ås NO-1432, Norway
}

\begin{abstract}
Chronic subclinical mastitis (SCM) is characterized by a long-term inflammation in the udder with high somatic cell count (SCC) in milk. Previously, several novel alternative SCM traits for Norwegian Red (NR) cattle have been defined to improve breeding strategies against chronic SCM. Quantitative trait loci and candidate genes affecting chronic SCM in NR have been identified. The aim of this study was to analyze the expression profiles of 14 selected candidate genes (RAD17, ACOT2, ACOT4, FOS, CXCL1, CXCL8, CCNB1, CDK\%, TGFB3, SEL1L, STAT4, C6, GLI2, and SLC18A2). Twenty healthy NR cows with official genomic estimated breeding values (GEBV) for lactation average somatic cell scores (LSCS) were selected. Ten cows had high GEBV for LSCS (cows with low probability to have high SCC in milk during lactation) and 10 cows had low GEBV for LSCS (cows with high probability of having high SCC in milk). We isolated RNA from unstimulated peripheral blood mononuclear cells from these. Two out of the 14 analyzed genes showed significantly different results between groups. The group with high GEBV for LSCS displayed significantly higher expression of the CXCL1 gene than the low GEBV group. Grouping by lactation stage revealed significant differential expression of the FOS gene, with higher expression in early lactation (2-3 mo after calving) compared with late lactation (7-8 mo after calving). In addition, flow cytometry was performed on the peripheral blood mononuclear cells samples to analyze if number and type of isolated cells influenced the gene expression in the groups. The results in the current study provide identified genes that can be considered as possible candidate genes for chronic SCM in NR cows.
\end{abstract}

Received January 7, 2020.

Accepted May 25, 2020.

*Corresponding author: elena.kirsanova@nmbu.no
Key words: RNA expression-profile, peripheral blood mononuclear cells, dairy cattle, somatic cell count

\section{INTRODUCTION}

Chronic subclinical mastitis (SCM) is a complex trait, characterized by increased SCC in milk (Harmon, 1994). It is a frequent disease that leads to economic loss due to reduced milk production and culling of animals. It is often characterized by inflammatory response in the mammary gland, mostly caused by environmental or pathogenic microorganisms (Oviedo-Boyso et al., 2007). One of the bacterial species known to cause subclinical bovine mastitis is Streptococcus agalactiae. Studies on expression profiles have been performed to identify genes associated with susceptibility to mastitis in dairy cattle (Fonseca et al., 2009; LewandowskaSabat et al., 2018). MicroRNA and mRNA expression profiles of bovine monocyte-derived macrophages stimulated in vitro with different strains of $S$. agalactiae have been analyzed on Norwegian Red (NR) cattle (Lewandowska-Sabat et al., 2018; Lewandowska-Sabat et al., 2019).

The peripheral blood mononuclear cells (PBMC) consist of lymphocytes and monocytes, and the latter can differentiate into macrophages. Monocytes and macrophages are the first line of the innate immune response cells that react against invading pathogens, and macrophages are present in the mammary gland in the bovine udder (Sarikaya et al., 2006). The macrophages have an ability to perform phagocytosis and produce proinflammatory and anti-inflammatory cytokines that have an essential role in defense against invading bacteria and other pathogens. The PBMC have been used to study the pathogenic mechanisms in disease processes and expression profiles of genes in cattle (MacHugh et al., 2009). Therefore, analysis of PBMC constitute a valid and well-documented method for analysis of gene expression profiles in infected and healthy cows. 
Elevated SCC in milk is an indicator of mastitis, and thus SCC is commonly used in the genetic evaluation of udder health. Genomic estimated breeding values (GEBV) for lactation average somatic cell scores (LSCS) are included in the routine genetic evaluation of NR and in the total merit index used for selection (Geno SA, 2018). Recent research has shown significant differentially expressed genes between groups of NR cows with high and low GEBV for LSCS, respectively (Lewandowska-Sabat et al., 2019). In the group of animals with high GEBV for LSCS, myosin IF (MYO1F) was found to be upregulated, and peptidyl arginine deiminase 4 (PADI4) was downregulated in bovine monocyte-derived macrophages stimulated with $S$. agalactiae strain ST103 or strain ST12, respectively.

In a previous study (Kirsanova et al., 2019), we defined novel alternative chronic SCM traits for NR by analyzing genotype data from NR bulls with corresponding test day SCC records of their daughters. Moreover, genes associated with the novel defined traits were identified (Kirsanova et al., 2020). The aim of the present study was to perform further functional analysis of the identified genes. Expression profiles of 14 selected candidate genes for chronic SCM were investigated in unstimulated samples of PBMC from groups of NR cows with high and low GEBV for LSCS, respectively. In parallel, the PBMC samples were assessed for cellular composition by flow cytometry to identify differences in number and types of cells as potential sources for differential gene expression.

\section{MATERIALS AND METHODS}

\section{Animals and PBMC Isolation}

Twenty healthy NR cows (presented in Table 1) from the research herd at Ås gård, Norwegian University of Life Sciences, were selected based on parity (1-6), stage of lactation (from 1-8 mo after calving), and official GEBV for LSCS. Ten cows with low GEBV for LSCS $(<100)$ and 10 cows with high GEBV for LSCS $(>100)$ were selected. High GEBV for LSCS is favorable, and cows with LSCS index above 100 have a higher probability than average to keep a low SCC in milk during the lactation period. Sampling of blood was performed by certified personnel and the study was approved by the Norwegian Animal Research Authority (Norwegian Food Safety Authority, FOTS identification 16486). Ten milliliters of blood from each individual were collected from the tail in ethylenediaminetetraacetic acid (EDTA) tubes. The PBMC were isolated from the blood samples using lymphoprep (Axis-Shield, Norway) and density gradient centrifugation $(30 \mathrm{~min}, 2,210 \times$ $g)$. After isolation, aliquots of the cells were either used
Table 1. Twenty healthy Norwegian Red cows selected based on genomic estimated breeding values (GEBV) for lactation average somatic cell score (LSCS) presented with LSCS index, parity, stage of lactation, and SCC per November 2018 (the date of collection of the blood samples)

\begin{tabular}{lrrlr}
\hline Sample & $\begin{array}{r}\text { LSCS } \\
\text { index }\end{array}$ & Parity & $\begin{array}{l}\text { Stage of } \\
\text { lactation }\end{array}$ & $\begin{array}{r}\text { SCC } \times 1,000 \\
\text { cells } / \mathrm{mL} \text { of milk }\end{array}$ \\
\hline s1 & 118.4 & 6 & Early & 90 \\
s2 & 99.5 & 6 & Early & 120 \\
s3 & 93.6 & 3 & Late & 70 \\
s4 & 120.5 & 3 & Late & 20 \\
s5 & 114.5 & 2 & Late & 10 \\
s6 & 89.7 & 2 & Late & 70 \\
s7 & 97.0 & 2 & Early & 20 \\
s8 & 110.6 & 2 & Early & 10 \\
s9 & 97.9 & 2 & Early & 20 \\
s10 & 107.1 & 1 & Early & 10 \\
s11 & 114.0 & 1 & Early & 40 \\
s12 & 106.4 & 2 & Late & 110 \\
s13 & 114.3 & 1 & Early & 20 \\
s14 & 99.1 & 1 & Late & 10 \\
s15 & 114.4 & 1 & Late & 40 \\
s16 & 98.9 & 1 & Late & 50 \\
s17 & 110.5 & 1 & Early & 10 \\
s18 & 87.1 & 1 & Early & 10 \\
s19 & 95.8 & 1 & Early & 10 \\
s20 & 89.8 & 1 & Early & 40 \\
\hline
\end{tabular}

${ }^{1} \mathrm{LSCS}$ index $=$ official GEBV for LSCS.

${ }^{2}$ Stage of lactation is defined as early period (1-2 mo after calving, $\mathrm{n}$ $=12$ ) and late period ( $7-8$ mo after calving, $\mathrm{n}=8)$.

for flow cytometry or snap frozen in liquid nitrogen and stored at $-86^{\circ} \mathrm{C}$ for later extraction of total RNA.

\section{Flow Cytometry}

Flow cytometric analysis was performed on fresh PBMC cell suspensions. Cells were first stained with LIVE/DEAD Fixable yellow dead cell stain kit (Life Technologies, Carlsbad, CA) for $10 \mathrm{~min}$ on ice. The washed cells were then incubated for $20 \mathrm{~min}$ on ice with mixes of primary monoclonal antibodies as listed in Supplemental Table S1.1 (https://doi.org/10.3168/ jds.2020-18170). Subsequently, washed cells were incubated for 20 min on ice with mixes of secondary isotypespecific antibodies as listed in Supplemental Table S1.2 (https://doi.org/10.3168/jds.2020-18170). Finally, cells were washed and fixed for $10 \mathrm{~min}$ at room temperature using FACS lysing solution (BD Biosciences, San Jose, $\mathrm{CA}$ ), washed with the same solution as previously (according to manufacturer's protocol), and resuspended with staining buffer until analysis within the same or next few days. All reagents were used at previously determined optimal concentrations. Stained samples were run in a 3-laser Gallios flow cytometer (Beckman Coulter, Brea, CA). Compensation matrices were resolved using single stain controls. Data were analyzed using Kaluza 2.1 software (Beckman Coulter; www.beckman 
.com). Gating strategies (Supplemental Figure S1, https://doi.org/10.3168/jds.2020-18170) were set using secondary antibody-only controls, and gross leukocyte subsets were defined as follows: monocyte gate $=$ high side scatter, showing monocytes $=\mathrm{CD} 172 \mathrm{a}^{\text {high }} / \mathrm{CD} 26^{-}$, and dendritic-like cells $=\mathrm{CD} 172 \mathrm{a}^{\text {low }} / \mathrm{CD} 26^{+}$(Hussen et al., 2013; Talker et al., 2018). Lymphocyte gate = low side scatter, showing B-cells $=$ sum of $\mathrm{CD} 21^{+}$and $\mathrm{BB}^{+}$, natural killer $(\mathrm{NK})$ cells $=\mathrm{NKp} 46^{+} / \mathrm{CD}^{-}$(Storset et al., 2004), T-cells $=\mathrm{CD}^{+}$divided into $\gamma \delta \mathrm{T}$-cells $\left(\mathrm{TCR} 1^{+}\right)$and $\alpha \beta \mathrm{T}$-cells $\left(\mathrm{TCR} 1^{-}\right)$, the latter further divided into $\mathrm{CD} 8^{+}$and $\mathrm{CD} 4^{+}$, and finally $\mathrm{TCR}^{-} / \mathrm{CD}^{+} /$ $\mathrm{CD} 25^{+}$comprising activated and regulatory $\alpha \beta T$-cells.

\section{Selection of Candidate Genes}

Fourteen candidate genes [RAD1\%, ACOT2, ACOT4, FOS, CXCL1 (also known as GRO1), CXCL8 (also known as IL8), CCNB1, CDK 7, TGFB3, SEL1L, STAT4, C6, GLI2, AP1, SLC18A2] presented in Table 2 and 3 were selected based on the results from a genome-wide association study of alternative chronic SCM traits (Kirsanova et al., 2020). The most frequent genes involved in several canonical pathways associated with several defined traits or unique genes were analyzed. The genes were located within converted bovine topologically associated domains (as converted from mouse and human) containing single nucleotide polymorphisms that were significantly associated with several novel defined SCM traits described previously (Kirsanova et al., 2019).

\section{RNA Extraction and Reverse Transcription- Quantitative PCR Analysis}

Total RNA was extracted from PBMC using the MirVANA isolation kit (Ambion, Austin, TX) in accordance with the manufacturer's instructions, and subsequently treated with amplification grade DNase I (Invitrogen, Carlsbad, CA) to ensure removal of any traces of genomic DNA. The RNA concentration was measured using NanoDrop 1000 (Thermo Fisher Scientific, Wilmington, DE). For reverse transcription, $500 \mathrm{ng}$ of RNA per sample was used as template for cDNA synthesis employing the Tetro cDNA synthesis kit (Nordic BioSite, Oslo, Norway) according to the manufacturer's protocol. For 1 qPCR reaction, cDNA equivalent to 5 ng of total RNA was used. We performed qPCR using Express SYBR GreenER SuperMix with premixed ROX (Invitrogen) according to the manufacturer's protocol, and used a 7900HT Fast Real-Time PCR System (Applied Biosystems, Foster City, CA) with standard program: $50^{\circ} \mathrm{C}$ for $2 \mathrm{~min}, 95^{\circ} \mathrm{C}$ for $2 \mathrm{~min}$ followed by 40 cycles with first $95^{\circ} \mathrm{C}$ for $15 \mathrm{~s}$ and then $60^{\circ} \mathrm{C}$ for $1 \mathrm{~min}$,

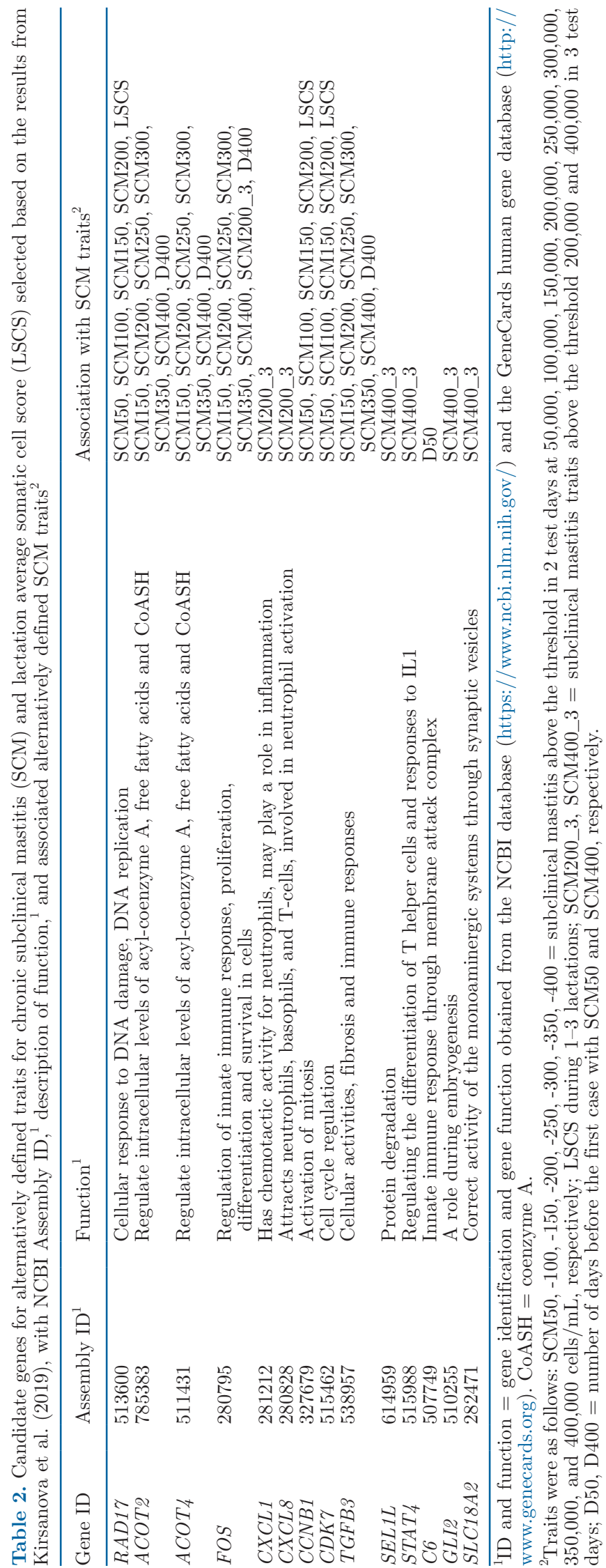

Journal of Dairy Science Vol. 103 No. 10, 2020 
with final melting curve analysis included. The qPCR was set up for triple reactions for each sample with each specific primer pair. The efficiencies of all primer pairs were tested by template dilution series using pooled PBMC cDNA from 3 cows with a low and 3 cows with a high official GEBV index for LSCS and were found to be $100 \%( \pm 10)$. Additionally, a control with no reverse transcription was included for each sample to check for genomic DNA contaminations, and negative controls with no added template was run for each primer pair.

Results from the qPCR reactions were analyzed in RQ Manager 1.2 (Applied Biosystems) with accepted standard deviation of $\leq 0.3$ per triplicate. The $\Delta \mathrm{Ct}$ method was used to calculate gene expression compared with 2 reference genes (i.e., $\Delta \mathrm{Ct}=\mathrm{Ct}_{\text {target gene }}-$ $\left.\mathrm{Ct}_{\text {reference gene }}\right)$, and normalized gene expression was defined as $2^{(-\Delta \mathrm{Ct})}$. The geNORM 6 gene bovine reference gene selection kit (Primerdesign Ltd., Southampton, UK) and the software qbase +3.2 (www.qbaseplus.com) was used to identify the most stable reference genes for PBMC derived from bovine blood. The optimal normalization factor, for instance the average expression stability value (M) lower than 0.3 , was calculated as the geometric mean of the reference targets eukaryotic translation initiation factor $2 \mathrm{~B}$ subunit $\beta$ (EIF2B2) and ribosomal protein L12 (RPL12), hence they were used as reference genes. Primers for each of the other genes were designed using the Primer-BLAST tool (Ye et al., 2012), avoiding single nucleotide polymorphisms in the primer sequences as far as known in the NR genome, no $\mathrm{G}$ on the 5 end, and max melting temperature difference of $2^{\circ} \mathrm{C}$ between the 2 primers. All primers are listed in Supplemental Table S2 (https://doi.org/10 .3168/jds.2020-18170). All of the designed primer pairs were tested on liver samples of NR by PCR followed by separation in 2\% agarose gels using 100 bp DNA ladder standard for verification of correct amplicon size.
Moreover, all of the PCR products were sequenced and correct gene sequence verified by BLAST against the bovine genome.

\section{Statistical Analyses}

GraphPad Prism version 8.1.1 (www.graphpad.com) was used for statistical analyses of the flow cytometry and gene expression results. Multiple $t$-test (1 unpaired $t$-test per row, $\mathrm{n}=11$ ) was performed using the approach recommended by GraphPad software as the 2-stage step-up method of Benjamini, Krieger and Yekutieli (Benjamini et al., 2006) with FDR (Q) $=5 \%$ used to define significant results. For more power of computation, it was assumed that all rows were samples from populations with the same scatter. The samples were grouped by high $(>100)$ and low $(<100)$ official GEBV for LSCS (Table 1). Further, samples were grouped by stage of lactation defined as early period (1-2 mo after calving, $\mathrm{n}=12)$ and late period $(7-8 \mathrm{mo}$ after calving, $\mathrm{n}=8)$.

\section{RESULTS}

Gene expression results for the GEBV for LSCS groups is displayed in Figure 1. In addition, gene expression normalized against the 2 reference genes EIF2B2 and RPL12 was calculated as $2^{(-\Delta \mathrm{Ct})}$ and is presented in Supplemental File S1 (https://doi.org/10 .3168/jds.2020-18170), with GraphPad Prism 8 analyses in Supplemental File S2 (https://doi.org/10.3168/ jds.2020-18170). Significant differential expression for the $C X C L 1$ gene $(P$-value $=0.0019, \mathrm{q}$-value $=0.02)$ was identified between the groups of cows with low or high GEBV for LSCS, with mean expression values of 1.19 and 1.90, respectively (Figure 1; Supplemental File $\mathrm{S} 1$ and S2). The gene FOS showed significant differ-

Table 3. Candidate genes analyzed for alternative chronic subclinical mastitis (SCM) traits (Kirsanova et al., 2019), with position in the bovine genome UMD3.1.1, ${ }^{1}$ GWAS significant single nucleotide polymorphism (SNP; Kirsanova et al., 2020), $P$-value for SNP, and topologically associated domain (TAD) region where the gene was identified

\begin{tabular}{lrcccc}
\hline Gene ID & BTA & Gene position & SNP position & $P$-value & TAD region \\
\hline RAD17 & 20 & $10,266,268-10,300,200$ & $10,493,654$ & $1.10 \mathrm{E}-06$ & $10,159,056-11,360,403$ \\
ACOT2 & 10 & $85,358,183-85,365,711$ & $87,958,006$ & $2.90 \mathrm{E}-06$ & $84,896,469-89,937,333$ \\
ACOT4 & 10 & $85,375,286-85,380,537$ & $87,958,006$ & $2.90 \mathrm{E}-06$ & $84,896,469-89,937,333$ \\
FOS & 10 & $86,883,739-86,887,170$ & $87,958,006$ & $2.90 \mathrm{E}-06$ & $84,896,469-89,937,333$ \\
CXCL1 & 6 & $90,822,721-90,824,859$ & $90,184,750$ & $4.00 \mathrm{E}-06$ & $89,308,822-90,824,904$ \\
CXCL8 & 6 & $90,559,882-90,563,647$ & $90,184,750$ & $4.00 \mathrm{E}-06$ & $89,308,822-90,824,904$ \\
CCNB1 & 20 & $10,431,452-10,441,126$ & $10,435,385$ & $1.60 \mathrm{E}-06$ & $10,407,200-11,354,566$ \\
CDK7 & 20 & $10,356,010-10,384,171$ & $10,493,654$ & $1.10 \mathrm{E}-06$ & $10,159,056-11,360,403$ \\
TGFB3 & 10 & $88,242,178-88,266,347$ & $87,958,006$ & $2.90 \mathrm{E}-06$ & $84,896,469-89,937,333$ \\
SEL1L & 10 & $93,900,621-93,965,136$ & $94,462,757$ & $4.30 \mathrm{E}-06$ & $93,958,242-100,721,748$ \\
STAT4 & 2 & $79,939,329-80,043,984$ & $75,996,043$ & $2.60 \mathrm{E}-06$ & $71,761,492-80,477,117$ \\
\hline
\end{tabular}

${ }^{1}$ UCSC Genome Browser assembly ID: bosTau8. 
ential expression based on $P$-value $(0.02)$, but not on q-value (0.13), for these 2 groups; mean expression was 2.35 in the low and 1.84 in the high GEBV for LSCS group. Grouping samples by stage of lactation also revealed differences. In the early period of lactation (1 or 2 mo after calving), the FOS gene displayed higher expression than later in the lactation (7-8 mo after calving), with expression 2.36 and 1.69 , respectively (Supplemental File S2, https://doi.org/10.3168/jds .2020-18170). The gene TGFB3 displayed a standard deviation higher than 0.3 for the triple reactions in samples 1 and 8 . The reactions were repeated using new primer mix and new cDNA samples without any changes in the results. This may be due to undiscovered polymorphisms in the primer regions making primer binding unstable. Samples 1 and 8 were excluded from further analysis, but no differential expression of this gene were observed among the remaining individuals $(\mathrm{n}=18)$. No detectable expression was observed in the samples for the genes SCL18A, C6, and GLI2.

To assess if differences in PBMC composition might influence differential gene expression, the PBMC samples were analyzed for lymphocyte subsets. The results are presented in Figure 2 and in Supplemental File S3 (lymphocyte composition; https://doi.org/10.3168/jds .2020-18170) and S2.2 (GraphPad Prism 8 analyses; https://doi.org/10.3168/jds.2020-18170). Supplemental Figure S1 (https://doi.org/10.3168/jds.2020-18170) presents the flow cytometric gating strategy showing representative plots of bovine PBMC. No significant differences for any of the leukocyte cells were found between the high and low GEBV for LSCS groups (Figure 2), nor when grouping the samples for early and late lactation (Supplemental File S4, https://doi.org/ 10.3168/jds.2020-18170).

\section{DISCUSSION}

In the present study we aimed to investigate selected candidate genes for chronic SCM traits to identify potential differences between groups of NR cows with high and low GEBV for LSCS. The CXCL1 gene was observed to have a higher level of expression in the group of cows with high GEBV for LSCS, that is, cows with expected low probability to get high SCC level in milk in compared with cows with low GEBV for LSCS. This gene was found in association with a long-term SCM trait with $\mathrm{SCC}>200,000$ cells $/ \mathrm{mL}$ during a 3 test-day period (Table 2; Kirsanova et al., 2020) and reported previously as upregulated after infection of monocyte cells with mastitis-causing bacteria (Lewandowska-Sabat et al., 2012; Han, 2019). In PBMC, the main sources of $C X C L 1$ are described to be monocytes and dendritic cells (Eberlein et al., 2010; Hussen et al., 2013). The differential CXCL1 expression was unlikely to be caused by elevated numbers of monocytes, dendritic cells, or any other cellular fractions in the PBMC, as all major cell subsets were similar in numbers, as measured by flow cytometry. This indicated a stronger constitutive cellular expression of $C X C L 1$ in the high GEBV for the LSCS group. The CXCL1 gene is involved in a massive influx of neutrophils to inflamed or

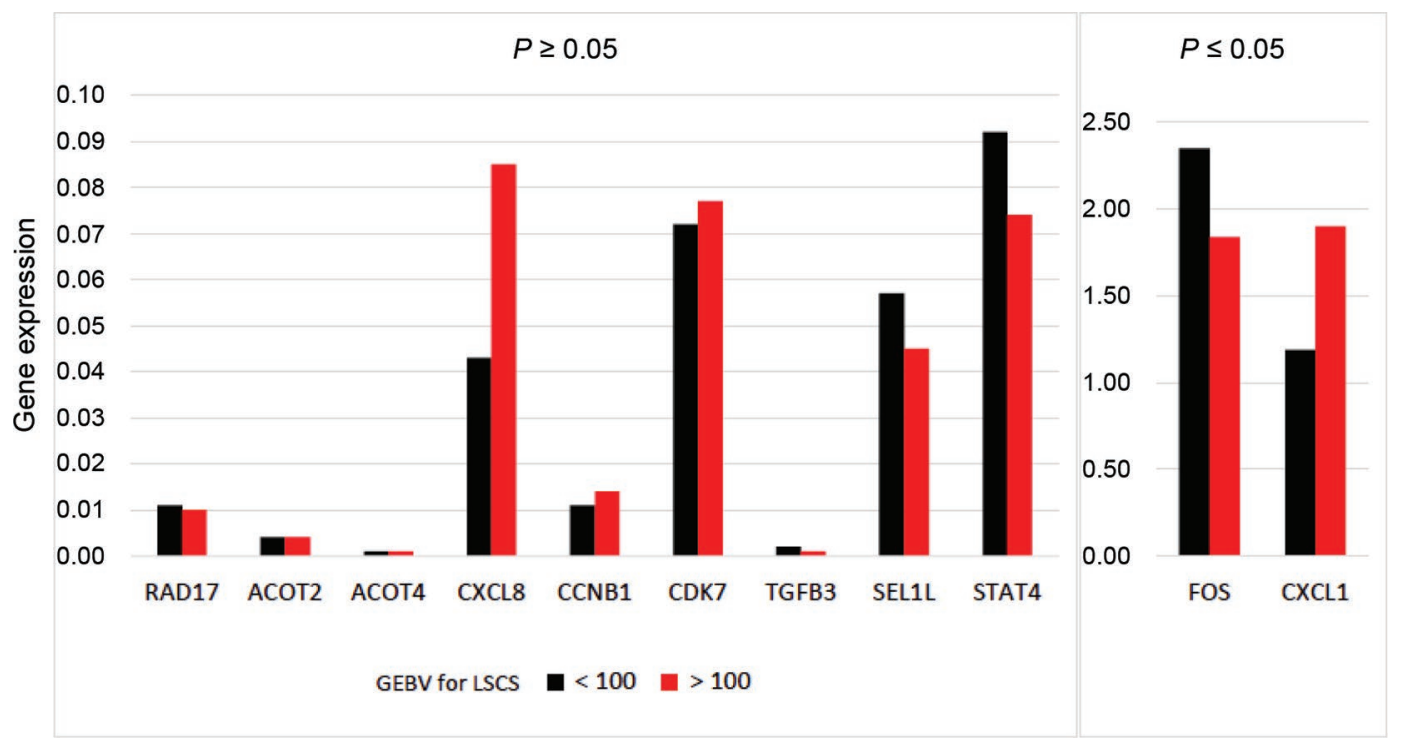

Figure 1. Gene expression measured by reverse transcription-quantitative PCR. The expression was normalized against 2 reference genes $\left(\right.$ EIF2B2 and RPL12) and calculated as $2^{(-\Delta \mathrm{Ct})}$, where $\mathrm{Ct}=$ cycle threshold. GEBV $=$ genomic estimated breeding values; LSCS $=$ lactation average somatic cell score. 


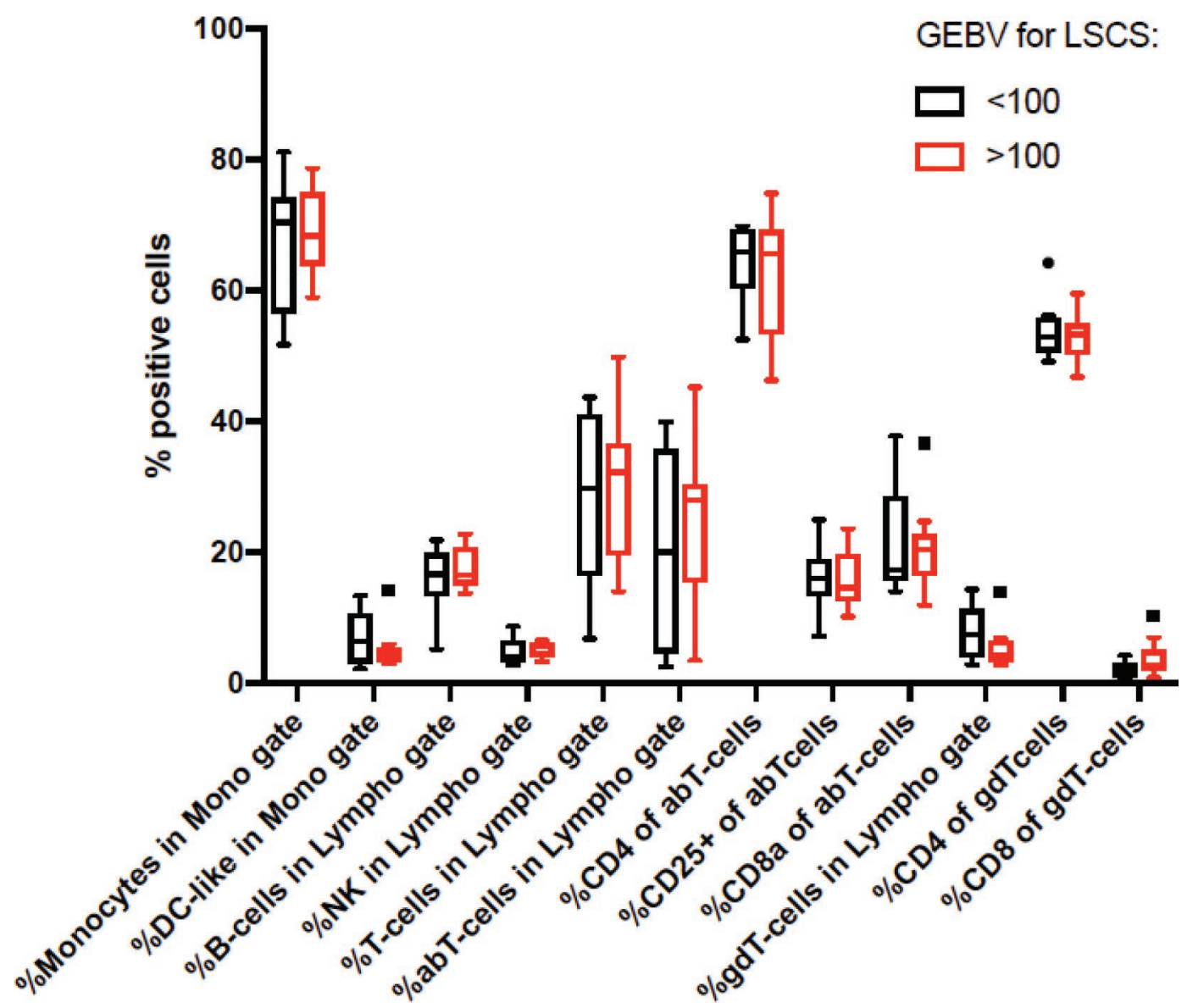

Figure 2. Leukocyte subsets investigated in groups of Norwegian Red cows with low $(<100)$ and high $(>100)$ official genomic estimated breeding value (GEBV) for lactation average somatic cell score (LSCS). Boxes enclose interquartile range, with midlines indicating median; whiskers extend to $\pm 1.5 \times$ interquartile range; dots indicate outliers. $\mathrm{NK}=$ natural killer; $\mathrm{DC}=$ dendritic cells.

infected tissue (Rainard et al., 2008; Sipka et al., 2014). A higher number of neutrophils has been reported in association with cortisol (stress-related hormone) concentration (Kulberg et al., 2002). Correspondingly, a higher number of neutrophils for cows with high milk production compared with average production has been reported for Holstein cows (Kimura et al., 1999), and in the case of stimulation with lipopolysaccharides, to activate the immune system (Dickson et al., 2019). In the current study, neutrophils were not quantified. The cows were healthy and had low SCC in milk at the time of sampling (Table 1). However, due to the higher CXCL1 gene expression, immune cells may react more quickly on invading pathogens in the udder, clearing the infection, and thus avoiding development of clinical mastitis or SCM with critical levels of SCC. Another gene, FOS, which was found to be significantly differentially expressed in our study, has previously been reported by several studies as significantly higher expressed in cells stimulated with different bacterial species (e.g., Staphylococcus aureus, Streptococcus uberis, and $S$. agalactiae), causing bovine mastitis (Lutzow et al., 2008; Naeem et al., 2012; Lewandowska-Sabat et al., 2013, 2019; Kosciuczuk et al., 2017). In addition, the FOS gene was found in association with a long-term chronic SCM200_3 trait with SCC >200,000 cells/mL during a 3 test-day period, similar to the CXCL1 gene (Table 2; Kirsanova et al. 2019). In the current study, FOS displayed higher expression in PBMC samples from cows with low GEBV for LSCS, but significant only based on $P$-value (0.02) results, and not significant for q-value (0.13), which may indicate false results. Further, the FOS gene was significantly higher expressed in the early compared with late lactation period (Supplemental File S2, https://doi.org/10.3168/ jds.2020-18170). Within the PBMC population, FOS is restricted to myeloid cells (Sariban et al., 1988), and as discussed for CXCL1, cell numbers cannot explain the differential FOS gene expression because monocytes were similar between the LSCS groups as well as between the lactation stage groups. This gene has an important role in regulation of the innate immune 
response through coordination of the induction of genes that encode inflammatory mediators (Guha and Mackman, 2001). Moreover, FOS plays a main role in proliferation, differentiation, and survival of cells (Bahrami and Drabløs, 2016) and is one of the immediate-early genes that can be activated and react within minutes after stimulation (Healy et al., 2013). Interestingly, the FOS gene showed lower expression in the high GEBV for LSCS group, which may indicate that a lower basic expression level leads to a fewer number of cells moving from blood to the infected tissue. This corresponds to the previously reported association of the FOS gene with SCM traits, with SCC threshold above 150,000 to 400,000 cells $/ \mathrm{mL}$ (Kirsanova et al., 2020). The association might be explained by higher expression of the FOS gene that leads to higher number of cells in milk. The present information on the expression of the CXCL1 and FOS genes might be useful for development of better strategies to improve immune response and eventually reduce subclinical infection in the mammary gland.

However, further investigation of candidate genes for chronic SCM is needed. Analysis of cows during periods of higher stress, such as close to parturition or during an udder infection, might reveal more important differences related to the genetic and molecular mechanisms involved in defense against infections.

\section{CONCLUSIONS}

Analyses of 14 candidate genes for chronic SCM in samples of PBMC from healthy NR cows revealed significant differential expression among the studied groups, with no influence from the number and type of lymphocyte subsets in the PBMC samples. The CXCL1 gene displayed higher and the FOS gene displayed lower expression in the group of cows with high GEBV for LSCS compared with the group with low GEBV for LSCS. Based on these results, the expression of $C X C L 1$ and FOS candidate genes for chronic SCM in NR can be used as additional information for selection to improve breeding for better udder health.

\section{ACKNOWLEDGMENTS}

Geno Breeding and AI Association (Hamar, Norway) and the Norwegian Dairy Herd Recording System (Oslo) are acknowledged for providing access to data. This work is part of the "Multimast" project (no. 233778) funded by the Research Council of Norway, Tine and Geno and coordinated by Norwegian University of Life Sciences (NMBU). We thank the staff at the research herd at the Norwegian University of Life Sciences ( $\AA s$ ) for help with collection of blood samples and head en- gineer Aleksandra Bodura Göksu (Oslo) for help with the gene expression analyses. The authors confirm that they have no conflicts of interest.

\section{REFERENCES}

Bahrami, S., and F. Drabløs. 2016. Gene regulation in the immediateearly response process. Adv. Biol. Regul. 62:37-49. https://doi .org/10.1016/j.jbior.2016.05.001.

Benjamini, Y., A. M. Krieger, and D. Yekutieli. 2006. Adaptive linear step-up procedures that control the false discovery rate. Biometrika. 93:491-507.

Dickson, M. J., S. K. Kvidera, E. A. Horst, C. E. Wiley, E. J. Mayorga, J. Ydstie, G. A. Perry, L. H. Baumgard, and A. F. Keating. 2019. Impacts of chronic and increasing lipopolysaccharide exposure on production and reproductive parameters in lactating Holstein dairy cows. J. Dairy Sci. 102:3569-3583. https://doi.org/10.3168/ jds.2018-15631.

Eberlein, J., T. T. Nguyen, F. Victorino, L. Golden-Mason, H. R. Rosen, and D. Homann. 2010. Comprehensive assessment of chemokine expression profiles by flow cytometry. J. Clin. Invest. 120:907-923. https://doi.org/10.1172/JCI40645.

Fonseca, I., P. V. Silva, C. C. Lange, M. F. Guimaraes, M. M. Weller, K. R. Sousa, P. S. Lopes, J. D. Guimaraes, and S. E. Guimaraes. 2009. Expression profile of genes associated with mastitis in dairy cattle. Genet. Mol. Biol. 32:776-781. https://doi.org/10.1590/ S1415-47572009005000074.

Geno, S. A. 2018. Total merit index. Accessed Jul. 26, 2020. https:/ /www.norwegianred.com/Start/Norwegian-Red/about-norwegian -red/Norwegian-Red-Total-Merit-Index/.

Guha, M., and N. Mackman. 2001. LPS induction of gene expression in human monocytes. Cell. Signal. 13:85-94. https://doi.org/10 .1016/S0898-6568(00)00149-2.

Han, H. 2019. Identification of several key genes by microarray data analysis of bovine mammary gland epithelial cells challenged with Escherichia coli and Staphylococcus aureus. Gene 683:123-132. https://doi.org/10.1016/j.gene.2018.10.004.

Harmon, R. J. 1994. Symposium - Mastitis and genetic evaluation for somatic-cell count - Physiology of mastitis and factors affecting somatic-cell counts. J. Dairy Sci. 77:2103-2112.

Healy, S., P. Khan, and J. R. Davie. 2013. Immediate early response genes and cell transformation. Pharmacol. Ther. 137:64-77. https: //doi.org/10.1016/j.pharmthera.2012.09.001.

Hussen, J., A. Duvel, O. Sandra, D. Smith, I. M. Sheldon, P. Zieger, and H. J. Schuberth. 2013. Phenotypic and functional heterogeneity of bovine blood monocytes. PLoS One 8:e71502. https://doi .org/10.1371/journal.pone.0071502.

Kimura, K., J. P. Goff, and M. E. Kehrli Jr.. 1999. Effects of the presence of the mammary gland on expression of neutrophil adhesion molecules and myeloperoxidase activity in periparturient dairy cows. J. Dairy Sci. 82:2385-2392. https://doi.org/10.3168/ jds.S0022-0302(99)75489-5.

Kirsanova, E., B. Heringstad, A. Lewandowska-Sabat, and I. Olsaker. 2019a. Alternative subclinical mastitis traits for genetic evaluation in dairy cattle. J. Dairy Sci. 102:5323-5329. https://doi.org/10 .3168/jds.2018-16104.

Kirsanova, E., B. Heringstad, A. Lewandowska-Sabat, and I. Olsaker. 2020. Identification of candidate genes affecting chronic subclinical mastitis in Norwegian Red cattle: Combining genome wide association study, topologically associated domains and pathway enrichment analysis. Anim. Genet. https://doi.org/10.1111/age.12886.

Kosciuczuk, E. M., P. Lisowski, J. Jarczak, A. Majewska, M. Rzewuska, L. Zwierzchowski, and E. Bagnicka. 2017. Transcriptome profiling of Staphylococci-infected cow mammary gland parenchyma. BMC Vet. Res. 13:161. https://doi.org/10.1186/s12917-017-1088 -2 .

Kulberg, S., A. K. Storset, B. Heringstad, and H. J. Larsen. 2002. Reduced levels of total leukocytes and neutrophils in Norwegian cat- 
tle selected for decreased mastitis incidence. J. Dairy Sci. 85:34703475. https://doi.org/10.3168/jds.S0022-0302(02)74435-4.

Lewandowska-Sabat, A. M., G. M. Boman, A. Downing, R. Talbot, A. K. Storset, and I. Olsaker. 2013. The early phase transcriptome of bovine monocyte-derived macrophages infected with Staphylococcus aureus in vitro. BMC Genomics 14:891. https://doi.org/10 $.1186 / 1471-2164-14-891$.

Lewandowska-Sabat, A. M., J. Gunther, H. M. Seyfert, and I. Olsaker. 2012. Combining quantitative trait loci and heterogeneous microarray data analyses reveals putative candidate pathways affecting mastitis in cattle. Anim. Genet. 43:793-799. https://doi.org/10 $.1111 /$ j.1365-2052.2012.02342.x.

Lewandowska-Sabat, A. M., S. F. Hansen, T. R. Solberg, O. Osteras, B. Heringstad, P. Boysen, and I. Olsaker. 2018. MicroRNA expression profiles of bovine monocyte-derived macrophages infected in vitro with two strains of Streptococcus agalactiae. BMC Genomics 19:241. https://doi.org/10.1186/s12864-018-4591-3.

Lewandowska-Sabat, A. M., E. Kirsanova, C. Klopp, T. R. Solberg, B. Heringstad, O. Østerås, P. Boysen, and I. Olsaker. 2019. Transcription profiling of monocyte-derived macrophages infected in vitro with two strains of Streptococcus agalactiae reveals candidate pathways affecting subclinical mastitis in cattle. Front. Genet. 10:689. https://doi.org/10.3389/fgene.2019.00689.

Lutzow, Y. C., L. Donaldson, C. P. Gray, T. Vuocolo, R. D. Pearson, A. Reverter, K. A. Byrne, P. A. Sheehy, R. Windon, and R. L. Tellam. 2008. Identification of immune genes and proteins involved in the response of bovine mammary tissue to Staphylococcus aureus infection. BMC Vet. Res. 4:18. https://doi.org/10.1186/1746-6148 $-4-18$.

MacHugh, D. E., E. Gormley, S. D. Park, J. A. Browne, M. Taraktsoglou, C. O'Farrelly, and K. G. Meade. 2009. Gene expression profiling of the host response to Mycobacterium bovis infection in cattle. Transbound. Emerg. Dis. 56:204-214. https://doi.org/10 $.1111 / \mathrm{j} .1865-1682.2009 .01082 . x$.

Naeem, A., K. Zhong, S. J. Moisa, J. K. Drackley, K. M. Moyes, and J. J. Loor. 2012. Bioinformatics analysis of microRNA and putative target genes in bovine mammary tissue infected with Streptococcus uberis. J. Dairy Sci. 95:6397-6408. https://doi.org/10.3168/ jds.2011-5173.

Oviedo-Boyso, J., J. J. Valdez-Alarcon, M. Cajero-Juarez, A. OchoaZarzosa, J. E. Lopez-Meza, A. Bravo-Patino, and V. M. Baizabal-
Aguirre. 2007. Innate immune response of bovine mammary gland to pathogenic bacteria responsible for mastitis. J. Infect. 54:399 409. https://doi.org/10.1016/j.jinf.2006.06.010.

Rainard, P., A. Fromageau, P. Cunha, and F. B. Gilbert. 2008. Staphylococcus aureus lipoteichoic acid triggers inflammation in the lactating bovine mammary gland. Vet. Res. 39:52. https://doi.org/10 .1051/vetres:2008034.

Sariban, E., T. Mitchell, A. Rambaldi, and D. W. Kufe. 1988. c-sis but not c-fos gene expression is lineage specific in human myeloid cells. Blood 71:488-493. https://doi.org/10.1182/blood.V71.2.488.488.

Sarikaya, H., G. Schlamberger, H. H. Meyer, and R. M. Bruckmaier. 2006. Leukocyte populations and mRNA expression of inflammatory factors in quarter milk fractions at different somatic cell score levels in dairy cows. J. Dairy Sci. 89:2479-2486. https://doi.org/ 10.3168/jds.S0022-0302(06)72322-0.

Sipka, A., S. Klaessig, G. E. Duhamel, J. Swinkels, P. Rainard, and Y. Schukken. 2014. Impact of intramammary treatment on gene expression profiles in bovine Escherichia coli mastitis. PLoS One 9:e85579. https://doi.org/10.1371/journal.pone.0085579.

Storset, A. K., S. Kulberg, I. Berg, P. Boysen, J. C. Hope, and E. Dissen. 2004. NKp46 defines a subset of bovine leukocytes with natural killer cell characteristics. Eur. J. Immunol. 34:669-676. https://doi.org/10.1002/eji.200324504.

Talker, S. C., A. Baumann, G. T. Barut, I. Keller, R. Bruggmann, and A. Summerfield. 2018. Precise delineation and transcriptional characterization of bovine blood dendritic-cell and monocyte subsets. Front. Immunol. 9:2505. https://doi.org/10.3389/fimmu.2018 .02505 .

Ye, J., G. Coulouris, I. Zaretskaya, I. Cutcutache, S. Rozen, and T. L. Madden. 2012. Primer-BLAST: a tool to design target-specific primers for polymerase chain reaction. BMC Bioinformatics 13:134. https://doi.org/10.1186/1471-2105-13-134.

\section{ORCIDS}

E. Kirsanova @ https://orcid.org/0000-0002-2841-4251

P. Boysen (® https://orcid.org/0000-0002-0084-1251

B. Heringstad (1) https://orcid.org/0000-0001-7388-3893

I. Olsaker ๑ https://orcid.org/0000-0003-2188-6595 